\title{
PERTUMBUHAN DAN HASIL DUA VARIETAS KACANG TANAH DALAM TUMPANGSARI REPLACEMENT SERIES DENGAN PADI BERAS HITAM SISTEM IRIGASI AEROBIK PADA BEDENG
}

\author{
Siti Zainab ${ }^{\text {a) }} *$, Wayan Wangiyana ${ }^{\text {b) }}$ \\ a) Fakultas Pertanian Universitas 45 Mataram \\ b) Fakultas Pertanian Universitas Mataram \\ *corresponding author: sitizainab83@gmail.com
}

\begin{abstract}
This study aimed to determine growth and yield of two varieties of peanut in a $2: 2$ replacement series intercropping system with black rice under aerobic irrigation system on raised-beds. The experiment, carried out on irrigated rice fields in South Kediri village (West Lombok, NTB) from May to August 2019, was arranged according to Split Split-Plot Design with three treatment factors, namely intercropping system as the main plots (T1: intercropping 2:2 rows between peanuts and black rice; T2: peanut monocrop), peanut varieties as the subplots (V1: Bison; V2: Hypoma-1 variety), and combinations of inorganic-organic-bio-fertilizers for black rice as the sub-sub-plots (P1: NPK fertilizer only; P2: NPK+Petroganik; P3: NPK+Petroganik+mycorrhiza biofertilizer). The intercropped peanut was fertilized only with $200 \mathrm{~kg} / \mathrm{ha}$ Phonska (NPK). The results indicated that the most influencing treatment factors were intercropping systems and combinations of inorganic-organic-biofertilizers. However, there were significant two-factor-interactions, namely between varieties and intercropping systems on peanut leaf number, dry stover weight and dry filled-pod weight, and between intercropping systems and fertilizer combinations on seed yield and harvest index. Dry seed yields were not significantly different between varieties, but were higher under P3 (21.17 g/clump) or P2 (20.67 g/clump) compared to P1 (19.35 g/clump), while peanut intercropped with black rice resulted in higher seed yield (22.10 g/clump) than monocroped peanuts (18.69 g/clump). Based on the interaction between intercropping systems and fertilizer combinations, the highest seed yield was obtained in peanuts intercropped with black rice fertilized with NPK+organic+bio-fertilizer $(23.65 \mathrm{~g} / \mathrm{clump})$ and the lowest average was in monocropped peanuts (17.87 g/clump).
\end{abstract}

Keywords: peanut; black rice; intercropping; replacement series; aerobic irrigation system

\begin{abstract}
Abstrak
Penelitian ini bertujuan untuk mengetahui pertumbuhan dan hasil dua varietas kacang tanah dalam sistem tumpangsari replacement series 2:2 dengan padi beras hitam pada bedeng sistem irigasi aerobik. Percobaan dilaksanakan pada sawah irigasi desa Kediri Selatan (Lombok Barat, NTB) dari bulan Mei sampai Agustus 2019, yang ditata menurut Split Split Plot Design dengan tiga faktor perlakuan, yaitu sistem tanam tumpangsari (T) sebagai petak utama (T1: tumpangsari 2:2 antara kacang tanah dan padi beras hitam; T2: monokrop kacang tanah), varietas kacang tanah (V) sebagai anak petak (V1: varietas Bison; V2: varietas Hypoma-1), dan kombinasi pemupukan anorganik-organik-hayati pada padi beras hitam (P) sebagai anak-anak petak (P1: pupuk NPK saja; P2: NPK+Petroganik; P3: NPK+Petroganik+mikoriza), sedangkan kacang tanah tumpangsari hanya dipupuk Phonska $200 \mathrm{~kg} / \mathrm{ha}$. Hasil penelitian menunjukkan bahwa faktor perlakuan yang paling berpengaruh adalah tumpangsari dan kombinasi pemupukan anorganik-organik-hayati. Namun, terdapat interaksi dua faktor, yaitu antara varietas dan sistem tumpangsari terhadap jumlah daun, berat berangkasan kering dan berat polong berisi, dan antara sistem tumpangsari dan kombinasi pupuk terhadap hasil biji dan indeks panen. Hasil biji kering tidak berbeda nyata antar varietas, tetapi lebih tinggi pada P3 (21,17 g/rumpun) atau pada P2 (20,67 g/rumpun) dibandingkan pada P1 yang hanya dipupuk NPK (19,35 g/rumpun), sedangkan tumpangsari dengan padi beras hitam memberikan hasil biji lebih tinggi (22,10 g/rumpun) dibandingkan kacang tanah monokrop (18,69 g/rumpun). Berdasarkan interaksi sistem tanam dan pemupukan, hasil biji mencapai rata-rata tertinggi pada kacang tanah yang ditumpangsari dengan padi beras hitam yang dipupuk NPK+organik+hayati $(23,65$ g/rumpun) dan terendah pada kacang tanah monokrop (17,87 g/rumpun).
\end{abstract}

Kata Kunci: kacang tanah; padi hitam; tumpangsari; replacement series; sistem irigasi aerobik 
How to Cite: Zainab, S. dan Wangiyana, W. (2021) 'Pertumbuhan dan hasil dua varietas kacang tanah dalam tumpangsari replacement series dengan padi beras hitam sistem irigasi aerobik pada bedeng', Jurnal Silva Samalas: Journal of Forestry and Plant Science, 4 (1), pp. 1-9.

\section{PENDAHULUAN}

Kacang tanah merupakan jenis kacang-kacangan yang menduduki urutan kedua setelah tanaman kedelai dan berpeluang besar untuk di kembangkan karena memiliki nilai ekonomi tinggi dan mempunyai nilai peluang pasar yang cukup besar. Jumlah konsumsi kacang tanah di Indonesia pada tahun 2020 sebesar 2,41\%. Kacang tanah termasuk komoditas yang multi fungsi, yaitu dapat dikonsumsi langsung dalam bentuk biji segar, dan dapat digunakan sebagai bahan baku industri berbagai jenis makanan olahan dan minyak nabati, serta batang dan daun untuk pakan ternak. Oleh karena itu, perkembangan industri pangan dan pakan ternak berbahan baku kacang tanah telah menyebabkan peningkatan permintaan terhadap kacang tanah dalam negeri. Meningkatnya permintaan kacang tanah merupakan peluang pasar yang besar bagi pengembangan produksi kacang tanah. Peningkatan pendapatan dan pengetahuan masyarakat tentang gizi telah mengubah pola konsumsi pangan masyarakat dari pangan karbohidrat penghasil energi ke pangan penghasil protein, baik hewani maupun nabati. Oleh karena itu, menurut Hutabarat (2003) permintaan pangan sumber protein akan terus meningkat seiring dengan pertumbuhan penduduk, urbanisasi, pendidikan, dan pendapatan masyarakat. Demikian juga halnya dengan permintaan terhadap kacang tanah sebagai salah satu sumber protein nabati. Kacang tanah merupakan salah satu komoditas pangan sumber protein dan minyak nabati yang bernilai ekonomi tinggi (Purba, 2012), namun popularitasnya tidak setinggi kedelai.

Di Indonesia, secara nasional kacang tanah belum dianggap sebagai komoditas unggulan (Harsono, 2012). Perhatian pemerintahpun tidak seperti halnya pada kedelai yang diprogramkan untuk mencapai swasembada. Program peningkatan produksi yang selama ini dilakukan untuk komoditas tanaman pangan baru terbatas pada padi, jagung, dan kedelai. Belum terdengar adanya kebijakan yang signifikan yang diluncurkan untuk kacang tanah. Oleh karena itu, teknologi budidaya yang diterapkan petani masih tradisional dan sederhana, sehingga produktivitasnya relatif masih rendah. Di Indonesia sebagian besar kacang tanah baru dimanfaatkan untuk makanan rumah tangga seperti: kacang rebus, kacang garing, kacang goreng, bumbu masakan, dan makanan ringan lainnya. Sebenarnya kacang tanah potensial untuk diolah dalam industri makanan menjadi berbagai produk makanan olahan seperti: aneka kue, susu nabati, tepung protein tinggi, es krim, dan minyak nabati (Santosa, 2009).

Namun demikian produksi kacang tanah masih relatif rendah di Indonesia. Salah satu cara untuk meningkatkan produksi adalah dengan penanaman varietas unggul. Varietas unggul merupakan salah satu komponen teknologi utama yang berperan penting dalam program peningkatan produksi kacang tanah. Dibandingkan dengan varietas unggul baru padi dan jagung hibrida, varietas baru kacangkacangan, terutama kacang tanah, relatif lambat diadopsi petani. Varietas unggul yang telah dilepas tersebut memiliki beberapa kelebihan dibandingkan dengan varietas lokal, misalnya dari segi produktivitas, umur dan toleransi terhadap cekaman biotik dan abiotik. Data yang tersedia menunjukkan bahwa dari 34 varietas unggul kacang tanah yang telah dilepas (26 tipe spanish dan 8 tipe valencia), hanya beberapa saja yang populer di kalangan petani (Kasno dan Harnowo, 2014).

Selain itu, untuk produksi kacang tanah di lahan sawah, maka ada persaingan lahan dengan komoditi padi karena petani akan selalu memilih untuk menanam padi jika ketersediaan air mencukupi untuk produksi padi sawah. Oleh karena itu, perlu dicarikan teknologi budidaya yang memungkinkan untuk menanam kacang tanah dalam tumpangsari dengan tanaman padi di lahan sawah irigasi. Tumpangsari merupakan suatu usaha penanaman beberapa jenis tanaman pada lahan dan waktu yang sama, yang diatur sedemikian rupa dalam barisan-barisan tanaman. Pada pola tanam tumpangsari sebaiknya dipilih dan dikombinasikan antara tanaman yang mempunyai perakaran yang relatif dalam dan tanaman yang mempunyai perakaran yang relatif dangkal (Warsana, 2013).

Namun demikian, tanaman padi yang dibudidakan dengan teknik konvensional tidak cocok ditanam tumpangsari dengan tanaman kacang tanah. Oleh karena itu, tanaman padi harus 
dibudidayakan dengan teknik budidaya sistem irigasi aerobik. Dari hasil beberapa penelitian, tanaman padi yang ditumpangsari secara sisipan (additive series) dengan tanaman kacang-kacangan, ternyata hadirnya tanaman kacang-kacangan yang disisipkan di antara baris tanaman padi mampu meningkatkan hasil padi, baik tumpangsari aditif dengan kacang tanah (Dulur et al., 2019; Wangiyana et al., 2017; 2020a; 2021a) maupun dengan kedelai (Wangiyana et al., 2018a; 2019; 2020b; 2021b) atau dengan kacang hijau (Wangiyana et al., 2018b).

Pertumbuhan dan hasil gabah padi beras hitam yang ditumpangsari secara replacement series juga lebih tinggi dibandingkan dengan padi beras hitam yang ditanam secara monokrop pada bedeng dengan sistem irigasi aerobik (Wangiyana et al., 2020c). Menurut Park et al. (2003), replacement series juga dapat digunakan untuk mempelajari interaksi interspesifik dan intraspesifik antar kombinasi tanaman. Replacement series dapat digunakan untuk mengkaji interaksi antara kedua tanaman dengan cara populasi optimum dari suatu jenis dikurangi dan diganti dengan tanaman dari jenis lain dengan jumlah yang sepadan, atau juga merupakan seri deret pengganti. Ada beberapa bentuk kompetisi yang terjadi di antara spesies tanaman yang dapat dianalisis secara diagram, tetapi bentuk interaksi yang umum terjadi dalam sistem tumpangsari replacement series yaitu komponen penyusun dapat saling merugikan (kompetitif), saling mengisi (suplementer) atau saling mendukung (komplementer). Penelitian ini bertujuan untuk mengatahui pertumbuhan dan hasil dua varietas kacang tanah yang ditanam dalam sistem tumpangsari replacement series 2:2 dengan padi beras hitam pada bedeng dengan sistem irigasi aerobik.

\section{METODE PELAKSANAAN}

Dalam penelitian ini digunakan petode eksperimental dengan melaksanakan percobaan lapangan di lahan sawah irigasi di dusun Dasan Tebu, desa Kediri Selatan, Lombok Barat, NTB dari bulan Mei sampai dengan Agustus 2019.

\section{a. Alat dan Bahan}

Bahan yang digunakan antara lain benih kacang tanah (varietas Bison dan Hypoma-1), benih padi beras hitam, Cruiser (insektisida perlakuan benih), Atonik (perangsang tumbuh), inokulan Rhizobium, pupuk Phonska, pupuk Urea, pupuk organik "Petroganik" dan pupuk hayati mikoriza "Technofert". Alat-alat yang digunakan meliputi alat lapangan (cangkul, sabit, meteran, ember, sprayer dan mesin pompa air untuk menaikkan air sumur untuk mengairi tanaman), dan alat tulis menulis.

\section{b. Rancangan Percobaan}

Percobaan ditata menurut Split Split Plot Design) dengan tiga faktor perlakuan, yaitu tumpangsari $(\mathrm{T})$ yang terdiri atas dua aras perlakuan (T1: tumpangsari replacement series 2:2 antara kacang tanah dan padi beras hitam; T2: monokrop kacang tanah) sebagai petak utama, varietas kacang tanah (V) yang terdiri atas dua aras perlakuan (V1: varietas Bison; V2: varietas Hypoma-1) sebagai anak petak, dan kombinasi pupuk yang diaplikasikan pada padi beras hitam dan kacang tanah $(\mathrm{P})$, yang terdiri atas tiga aras perlakuan (P1: pupuk NPK saja; P2: NPK + Petroganik; P3: NPK + Petroganik + mikoriza) sebagai anak-anak petak. Dengan demikian ada 12 kombinasi perlakuan yang masing-masing dibuat dalam empat blok.

\section{c. Cara Kerja}

Pelaksanaan percobaan secara detil adalah seperti yang diuraikan dalam Wangiyana et al. (2020c), kecuali varietas kacang tanah yang digunakan, yang dalam percobaan ini ada dua varietas kacang tanah (Bison dan Hypoma-1) and teknik budidaya padi yang digunakan hanya sistem irigasi aerobik pada bedeng.

Demikian pula teknik budidaya tanaman kacang tanah, yang dalam percobaan ini dilakukan teknik budidaya tumpangsari kacang tanah dengan padi beras hitam pada bedeng sistem irigasi aerobik dan teknik budidaya kacang tanah monokrop yang juga dilaksanakan pada bedeng. Berbeda dengan padi beras hitam, tanaman kacang tanah hanya dipupuk dengan Phonska (NPKS 15-15-15-10) dosis $200 \mathrm{~kg} / \mathrm{ha}$. Dosis anjuran Petroganik adalah 500-1000 kg/ha tetapi yang diaplikasikan ke padi adalah $1000 \mathrm{~kg} / \mathrm{ha}$ dan dosis pupuk hayati mikoriza $5 \mathrm{~g} / \mathrm{lubang}$ tanam. Karena padi yang tumpangsari 
dengan kacang tanah ada perlakuan P1, P2, P3, maka kacang tanah monokrop juga diberikan perlakuan P2 dan P3 dengan tambahan setengah dosis minimum dari Petroganik $(250 \mathrm{~kg} / \mathrm{ha})$ maupun pupuk hayati Technofert.

\section{d. Analisis Data}

Pengamatan kacang tanah dilakukan terhadap tinggi tanaman dan jumlah daun umur 56 hari, berat berangkasan kering, berat polong kering berisi, berat 50 biji, hasil biji kering, indeks panen, jumlah polong berisi dan hampa. Data dianalisis dengan ANOVA dan BNJ (Tukey's HSD) pada taraf $5 \%$ menggunakan program CoStat for Windows ver. 6.303. Grafik dibuat berdasarkan nilai mean dan standard error (SE) menurut Riley (2001).

\section{HASIL DAN PEMBAHASAN}

Rangkuman hasil ANOVA yang disajikan dalam Tabel 1 menunjukkan bahwa faktor perlakuan yang paling dominant pengaruhnya adalah tumpangsari, dan kombinasi pupuk organik-hayati, sedangkan kedua varietas kacang tanah hanya berbeda dalam hal jumlah daun dan jumlah polong hampa per rumpun. Namun demikian, terdapat interaksi dua faktor, yaitu interaksi antara sistem tanam dan pemupukan (Ppk*Sis) terhadap berat biji per rumpun dan indeks panen, dan interaksi antara sistem tanam dan varietas (Var*Sis) terhadap jumlah daun per rumpun, berat berangkasan kering per rumpun, dan berat polong berisi kering per rumpun.

Tabel 1. Rangkuman hasil ANOVA tinggi tanaman, jumlah daun, berat berangkasan kering (BBKr), jumlah polong berisi, jumlah polong hampa, berat polong berisi kering (BPBKr), berat biji per rumpun $(\mathrm{BB} / \mathrm{rpn})$, berat 50 biji, dan indeks panen

\begin{tabular}{lccccccccc}
\hline Sumber keragaman Tinggi tan Jmlh daun & BBKr & JPB/rpn & JPH/rpn & BPBKr & BB/rpn & B50 biji & IP\% \\
\hline Sistem tanam & $\mathrm{ns}$ & $\mathrm{ns}$ & $\mathrm{ns}$ & $*$ & $*$ & $*$ & $* * *$ & $* *$ & $* * *$ \\
Varietas & $\mathrm{ns}$ & $*$ & $\mathrm{~ns}$ & $\mathrm{~ns}$ & $* *$ & $\mathrm{~ns}$ & $\mathrm{~ns}$ & $\mathrm{~ns}$ & $\mathrm{~ns}$ \\
Var*Sis & $\mathrm{ns}$ & $*$ & $*$ & $\mathrm{~ns}$ & $\mathrm{~ns}$ & $*$ & $\mathrm{~ns}$ & $\mathrm{~ns}$ & $\mathrm{~ns}$ \\
Pupuk & $\mathrm{ns}$ & $\mathrm{ns}$ & $*$ & $\mathrm{~ns}$ & $* * *$ & $* * *$ & $* * *$ & $\mathrm{~ns}$ & $* * *$ \\
Ppk*Sis & $\mathrm{ns}$ & $\mathrm{ns}$ & $\mathrm{ns}$ & $\mathrm{ns}$ & $\mathrm{ns}$ & $\mathrm{ns}$ & $* * *$ & $\mathrm{~ns}$ & $* * *$ \\
Ppk*Var & $\mathrm{ns}$ & $\mathrm{ns}$ & $\mathrm{ns}$ & $\mathrm{ns}$ & $\mathrm{ns}$ & $\mathrm{ns}$ & $\mathrm{ns}$ & $\mathrm{ns}$ & $\mathrm{ns}$ \\
Ppk*Var*Sis & $\mathrm{ns}$ & $\mathrm{ns}$ & $\mathrm{ns}$ & $\mathrm{ns}$ & $\mathrm{ns}$ & $\mathrm{ns}$ & $\mathrm{ns}$ & $\mathrm{ns}$ & $\mathrm{ns}$ \\
\hline
\end{tabular}

Keterangan: $\mathrm{ns}=$ non-signifikan; $*, * *, * * *=$ signifikan pada $\mathrm{p}>0,05 ; \mathrm{p}>0,01 ;$ dan $\mathrm{p}>0,001$

Berdasarkan perbedaan penampilan antar varietas kacang tanah yang digunakan, dapat dilihat dari Tabel 2 bahwa kedua varietas hanya berbeda nyata dalam hal rata-rata jumlah polong hampa per rumpun dan jumlah daun per rumpun, di mana jumlah polong hampa (JPH) rata-rata lebih tinggi pada varietas Hypoma-1 $(7,75)$ daripada varietas Bison $(7,10)$, sebaliknya jumlah daun per rumpun ratarata lebih tinggi pada varietas Bison (79,71 trifoliat) daripada varietas Hypoma-1 (76,79 trifoliat). Namun demikian, terhadap jumlah daun per rumpun, terdapat interaksi antara faktor varietas dan faktor sistem tanam, di mana jumlah daun kacang tanah varietas Bison rata-rata lebih tinggi pada siste tanam monokrop kacang tanah daripada tumpangsari dengan padi beras hitam, sedangkan jumlah daun varietas Hypoma-1 tidak berbeda antar sistem tanam (Gambar 1).

Interaksi antara sistem tanam dan varietas kacang tanah juga signifikan terhadap berat berangkasan kering (Gambar 2) dan berat polong berisi kering per rumpun (Gambar 3). Dari Gambar 2 terlihat bahwa pada sistem tumpangsari, berat berangkasan kering tanaman kacang tanah lebih tinggi pada varietas Hypoma-1, sebaliknya pada sistem monokrop lebih tinggi pada varietas Bison, padahal jumlah daun per rumpun pada saat tanaman umur 56 hari setelah tanam (HST), tidak ada perbedaan antara kedua varietas kacang tanah pada sistem tumpangsari dengan padi beras hitam. Hal ini diduga karena daun varietas Bison lebih cepat rontok daripada Hypoma-1 sebelum panen polong kacang tanah. 
Bila dilihat dari interaksi antara varietas dan sistem terhadap berat polong kering berisi (Gambar 3), terlihat bahwa berat polong kerning berisi tertinggi pada varietas Bison tumpangsari dengan padi beras hitam. Menurut Sinclair dan de Wit (1975), tanaman kacang-kacangan membutuhkan pasokan $\mathrm{N}$ yang tinggi pada saat pengisian polong karena kandungan protein biji yang tinggi sehingga tanaman bersifat "self-destructive", yaitu lebih cepat rontok daunnya akibat remobilisasi unsur hara dari daun ke biji terutama Nitrogen. Dengan demikian, wajarlah berat berangkasan kering varietas Bison pada sistem tumpangsari menjadi lebih rendah padahal jumlah daunnya umur 56 HST pada sistem tumpangsari dengan padi beras hitam tidak berbeda antar kedua varietas (Gambar 1).

Tabel 2. Rerata tinggi tanaman, jumlah daun, berat berangkasan kering (BBKr), jumlah polong berisi, jumlah polong hampa, berat polong berisi kering (BPBKr), berat biji per rumpun $(\mathrm{BB} / \mathrm{rpn})$, berat $50 \mathrm{biji}$, dan indeks panen untuk setiap aras faktor kombinasi pupuk, varietas dan sistem

\begin{tabular}{|c|c|c|c|c|c|c|c|c|c|}
\hline Perlakuan & $\begin{array}{c}\text { Tingg tan } \\
(\mathrm{cm})\end{array}$ & $\begin{array}{c}\text { Jumlah } \\
\text { daun }\end{array}$ & $\begin{array}{c}\text { BBKr } \\
\text { (g/rumpun) }\end{array}$ & $\begin{array}{c}\text { JPB/ } \\
\text { rumpun }\end{array}$ & $\begin{array}{c}\text { JPH/ } \\
\text { rumpun }\end{array}$ & $\begin{array}{c}\mathrm{BPBKr} \\
\text { (g/rumpun) }\end{array}$ & $\begin{array}{c}\text { Berat biji } \\
\text { (g/rumpun) }\end{array}$ & $\begin{array}{c}\text { Berat } 50 \\
\text { biji }(\mathrm{g})\end{array}$ & $\begin{array}{c}\text { Indeks } \\
\text { panen }(\%)\end{array}$ \\
\hline \multicolumn{10}{|c|}{ Kombinasi Pupuk: } \\
\hline $\mathrm{P} 1$ & $66.51 \mathrm{a}^{1)}$ & $79.50 \mathrm{a}$ & $37.43 \mathrm{a}$ & $14.94 \mathrm{a}$ & $7.94 \mathrm{a}$ & $24.58 \mathrm{~b}$ & $19.35 \mathrm{~b}$ & $19.42 \mathrm{a}$ & $31.22 \mathrm{~b}$ \\
\hline $\mathrm{P} 2$ & $62.54 \mathrm{a}$ & $77.97 \mathrm{a}$ & $37.45 \mathrm{a}$ & $15.25 \mathrm{a}$ & $7.56 \mathrm{a}$ & $25.38 \mathrm{~b}$ & $20.67 \mathrm{a}$ & $19.13 \mathrm{a}$ & $32.92 \mathrm{a}$ \\
\hline $\mathrm{P} 2+\mathrm{M}$ & $64.78 \mathrm{a}$ & $77.28 \mathrm{a}$ & $36.05 \mathrm{~b}$ & $15.56 \mathrm{a}$ & $6.78 \mathrm{~b}$ & $26.56 \mathrm{a}$ & $21.17 \mathrm{a}$ & $19.08 \mathrm{a}$ & $33.86 \mathrm{a}$ \\
\hline BNJ $0.05=$ & 4.52 & 4.17 & 1.26 & 0.77 & 0.60 & 0.90 & 0.69 & 0.72 & 1.41 \\
\hline \multicolumn{10}{|l|}{ Varietas: } \\
\hline Bison & $66.44 \mathrm{a}$ & $79.71 \mathrm{a}$ & $36.75 \mathrm{a}$ & $15.27 \mathrm{a}$ & $7.10 \mathrm{~b}$ & $25.51 \mathrm{a}$ & $20.51 \mathrm{a}$ & $19.26 \mathrm{a}$ & $32.98 \mathrm{a}$ \\
\hline Hypoma-1 & $62.78 \mathrm{a}$ & $76.79 \mathrm{~b}$ & $37.20 \mathrm{a}$ & $15.23 \mathrm{a}$ & $7.75 \mathrm{a}$ & $25.50 \mathrm{a}$ & $20.29 \mathrm{a}$ & $19.15 \mathrm{a}$ & $32.35 \mathrm{a}$ \\
\hline BNJ $0.05=$ & 4.34 & 2.35 & 0.71 & 0.90 & 0.39 & 0.60 & 0.45 & 0.45 & 0.80 \\
\hline \multicolumn{10}{|l|}{ Sistem tanam: } \\
\hline Monokrop & $67.14 \mathrm{a}$ & $79.21 \mathrm{a}$ & $37.13 \mathrm{a}$ & $14.85 \mathrm{~b}$ & $7.98 \mathrm{a}$ & $25.33 \mathrm{~b}$ & $18.69 \mathrm{~b}$ & $18.30 \mathrm{~b}$ & $29.93 \mathrm{~b}$ \\
\hline $\begin{array}{l}\text { Tumpangsa } \\
\text { ri }\end{array}$ & $62.08 \mathrm{a}$ & $77.29 \mathrm{a}$ & $36.82 \mathrm{a}$ & $15.65 \mathrm{a}$ & $6.88 \mathrm{~b}$ & $25.68 \mathrm{a}$ & $22.10 \mathrm{a}$ & $20.12 \mathrm{a}$ & $35.40 \mathrm{a}$ \\
\hline BNJ $0.05=$ & 6.94 & 5.92 & 1.10 & 0.78 & 0.69 & 0.22 & 0.49 & 0.47 & 0.35 \\
\hline
\end{tabular}

${ }^{1)}$ Angka pada setiap kolom yang diikuti huruf yang sama, tidak berbeda nyata antar aras tiap faktor

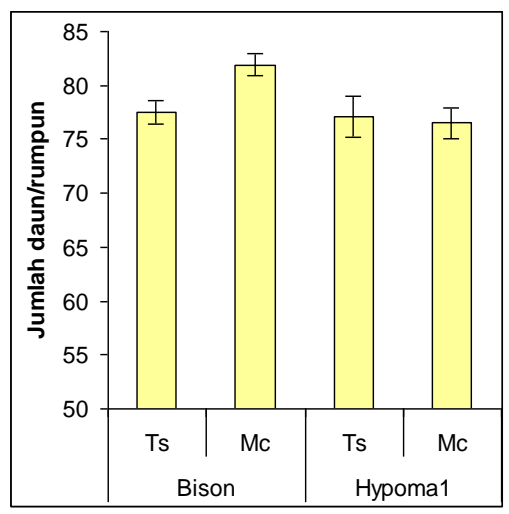

Gambar 1. Pola interaksi antara varietas dan sistem $(\mathrm{Ts}=$ tumpangsari; $\mathrm{Mc}=$ monokrop) terhadap jumlah daun

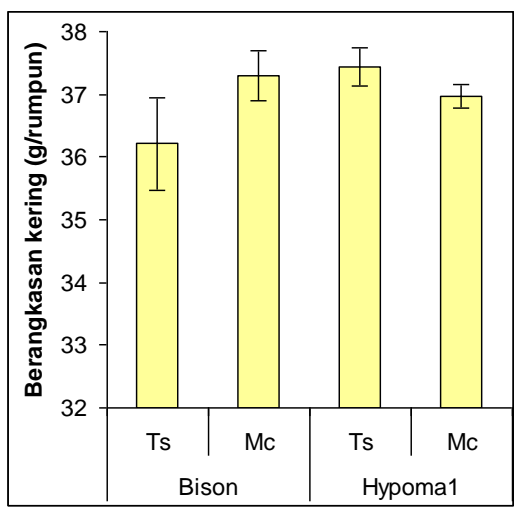

Gambar 2. Pola interaksi antara varietas dan sistem (Ts= tumpangsari; $\quad \mathrm{Mc}=$ monokrop) terhadap berat berangkasan kering

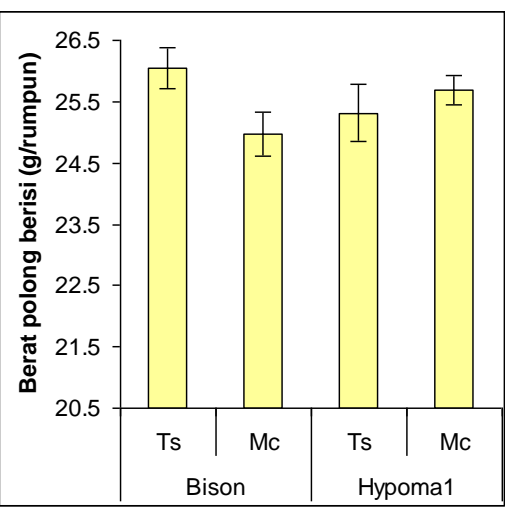

Gambar 3. Pola interaksi antara varietas dan sistem (Ts= tumpangsari; $\quad \mathrm{Mc}=$ monokrop) terhadap berat polong kering berisi

Dari Gambar 3 terlihat bahwa produktivitas tanaman kacang tanah varietas Bison lebih tinggi pada sistem tumpangsari dengan padi beras hitam sedangkan varietas Hypoma-1 cenderung lebih baik pada sistem monokrop dibandingkan dengan tumpangsari dengan tanaman padi beras hitam. Hal ini 
mengindikasikan bahwa varietas Bison lebih cocok ditanam tumpangsari dengan padi beras hitam dibandingkan dengan varietas Hypoma-1.

Berdasarkan pola interaksinya antara sistem tanam dan kombinasi pupuk anorganik-organikhayati, yang signifikan terhadap berat biji kering per rumpun (Gambar 4) dan indeks panen (Gambar 5), dapat dilihat dari Gambar 4 bahwa penambahan aplikasi pupuk organik (P2) maupun organik dan hayati mikoriza $(\mathrm{P} 2+\mathrm{M})$ pada padi beras hitam signifikan meningkatkan hasil biji kacang tanah dalam tumpangsari dengan padi beras hitam. Sebaliknya, penambahan pupuk organik dan mikoriza pada kacang tanah monokrop malah menurunkan hasil biji.

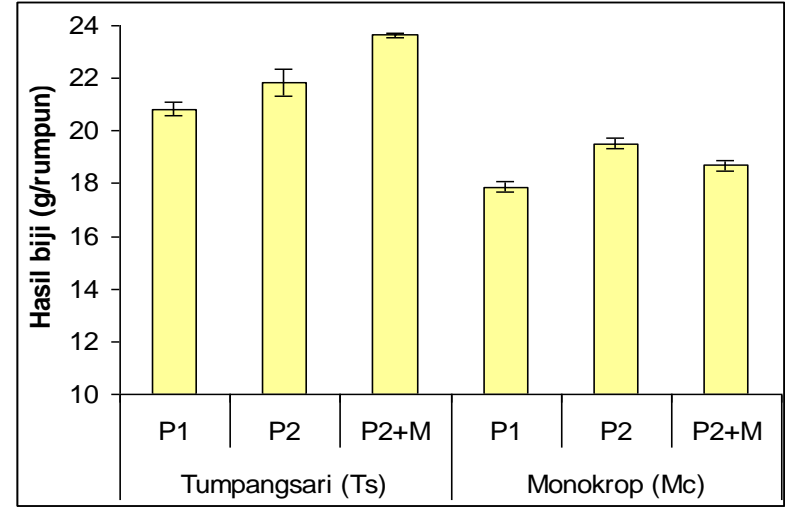

Gambar 4. Pola interaksi antara sistem dan pemupukan terhadap hasil biji kacang tanah (g/rumpun)

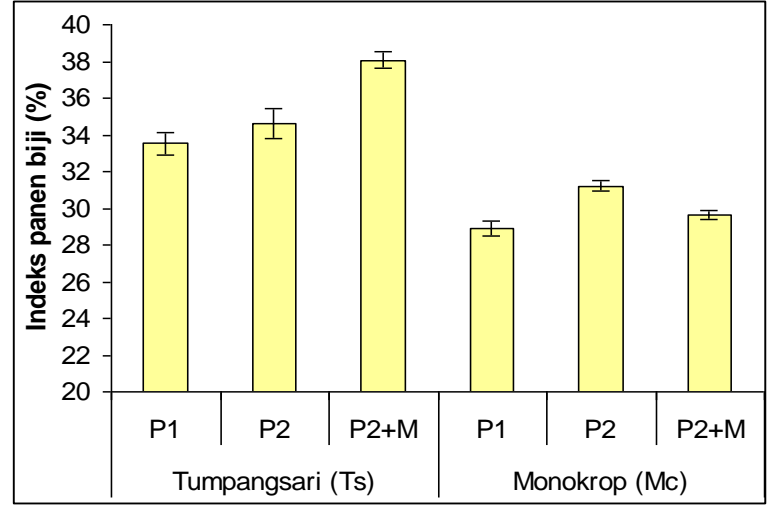

Gambar 5. Pola interaksi antara sistem dan pemupukan terhadap indeks panen $(\%)$

Lebih rendahnya hasil biji pada kacang tanah monokrop (Tabel 2) dibandingkan dengan hasil pada tumpangsari dengan padi beras hitam, terutama sekali pada perlakuan P3 (dengan tambahan pupuk organic dan hayati) sangat berkaitan dengan indeks panen (pola interaksinya mirip dengan indeks panen). Selain itu, berdasarkan analisis "Best Subset Regression), regresi berat biji per rumpun sebagai variabel respon (Y) menghasilkan nilai $\mathrm{R}^{2}$ paling tinggi dengan indeks panen, dengan nilai $\mathrm{R}^{2}$ $=92,4 \%$ (p-value $<0,001)$, dengan persamaan regresi $\mathrm{Y}=1.26+0.586 \mathrm{X}(\mathrm{Y}=$ berat biji per rumpun; $\mathrm{X}=$ indeks panen).

Bila dilihat dari Gambar 6, terlihat bahwa daun-daun kacang tanah pada bedeng monokrop kacang tanah sangat rimbun dan tidak memungkinkan cahaya matahari menembus ke bagian engah dan bawah kanopi, sehingga daun-daun tengah dan bawah tidak berfotosintesis selama fase pengisian polong. Sebaliknya, tanaman kacang tanah dalam tumpangsari dengan padi beras hitam masih ada peluang untuk mendapatkan lebih banyak cahaya per rumpun dibandingkan kacang tanah pada bedeng monokrop, terutama pada pagi atau sore hari, dari sela-sela daun padi beras hitam masih ada cahaya yang masuk ke daun-daun pada bagian tengah dan bawah kanopi. Dengan demikian, laju pengisian biji berpeluang menjadi lebih tinggi pada tanaman kacang tanah dalam tumpangsari dengan padi beras hitam dibandingkan kacang tanah monokrop, sehingga indeks panen bisa lebih tinggi pada tanaman kacang tanah tumpangsari dengan padi beras hitam dibandingkan dengan kacang tanah monokrop. Demikian pula hasil bijinya seperti tampak dari grafik interaksi pada Gambar 4.

Selain itu, dari beberapa penelitian yang dilaporkan oleh beberapa peneliti terdahulu, bahwa ketersediaan unsur hara pada risozfir tanaman tumpangsari, seperti pada tumpangsari jagun dan kacang tanah, jauh lebih tinggi dibandingkan pada rizosfir masing-masing tanaman pada sistem monokrop, yang juga menyebabkan serapan hara menjadi lebih tinggi pada tanaman tumpangsari dibandingkan dengan monokrop (Inal et al., 2007). Pada percobaan pot, Iryani et al. (2019) melaporkan beberapa varietas kacang tanah memberikan berat dan jumlah biji yang lebih tinggi pada tumpangsari dengan padi beras merah dibandingkan dengan pada sistem monokrop kacang tanah, seperti varietas Biawak dan local Sumbawa ("Wajik").

Berdasarkan hasil percobaan pot, Chu et al. (2004) juga melaporkan bahwa produksi berat kering, baik berat kering akar maupun berat kering bagian tanaman di atas tanah (shoot), lebih tinggi pada tanaman kacang tanah dalam sistem tumpangsari dengan padi dibandingkan dengan kacang 
tanah monokrop, terutama pada dosis pupuk $\mathrm{N}$ yang rendah, seperti juga dilaporkan oleh Shen dan Chu (2004). Shen dan Chu (2004) juga melaporkan adanya transfer $N$ dua arah antara padi dan kacang tanah pada sistem tumpangsari. Xue et al. (2016) juga menyatakan bahwa ada fasilitasi bawah tanah jika kacang-kacangan ditumpangsarikan dengan tanaman serealia karena serealia mampu meningkatkan ketersediaan (bio-availability) Fe dan Zn yang menguntungkan bagi kacang-kacangan dalam tumpangsari dengan serealia.

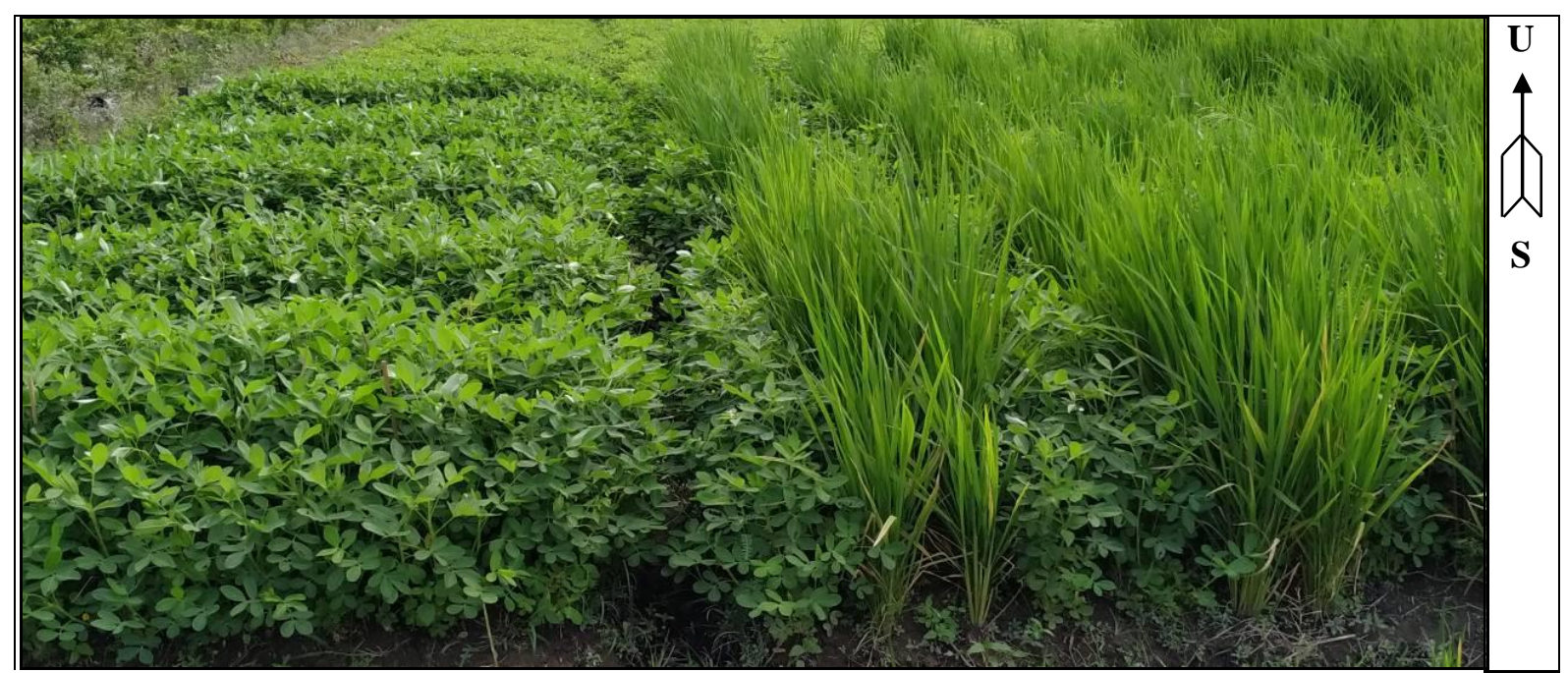

Gambar 6. Pertumbuhan tanaman kacang tanah pada sistem monokrop lebih rimbun dan daun-daun di bagian tengah dan bawah kanopi menjadi ternaungi jika dibandingkan dengan pertumbuhan kacang tanah dalam tumpangsari 2:2 dengan padi beras hitam sistem isigasi aerobik

Adanya keterlibatan FMA (fungi mikoriza arbuskular) yang terkandung di dalam pupuk hayati mikoriza "Technofert" juga dapat meningkatkan ketersediaan (bio-availability) unsur hara terutama $\mathrm{P}$ di dalam rizosfir tanaman kacang tanah dan padi beras hitam dalam sistem tumpangsari, yang dapat lebih memfasilitasi transfer hara antar spesies tanaman yang ditumpangsarikan, seperti yang dinyatakan oleh Bethlenfalvay et al. (1991) dan Hamel dan Smith (1991). Hasil penelitian Wangiyana et al. (2021b) juga menunjukkan bahwa aplikasi pupuk hayati mikoriza dan tumpangsari dengan kedelai signifikan meningkatkan hasil gabah dan kandungan antosianin beras pada dua galur padi gogo beras merah yang dibudidayakan dengan sistem irigasi aerobik pada bedeng permanen. Jadi, tumpangsari padi beras hita dengan kacang tanah selain meningkatkan hasil gabah padi beras hitam (Wangiyana et al., 2020c) juga meningkatkan hasil tanaman kacang tanah yang ditumpangsarikan dengan padi beras hitam, tetapi dari dua varietas kacang tanah yang diuji dalam penelitian ini, ada perbedaan daya hasil jika sama-sama ditumpangsarikan dengan padi beras hitam, yaitu lebih cocok menggunakan varietas Bison dibandingkan dengan varietas Hypoma-1 (Gambar 3).

\section{KESIMPULAN}

Berdasarkan hasil analisis data yang diperoleh, dapat disimpulkan bahwa tanaman kacang tanah dapat ditumpangsarikan dengan tanaman padi beras hitam, apalagi jika dilakukan pemupukan tambahan dengan pupuk organik dan pupuk hayati mikoriza, tetapi di antara dua varietas kacang tanah yang diuji, daya hasil berupa berat polong berisi pada sistem tumpangsari lebih tinggi pada varietas Bison dibandingkan dengan Hypoma-1.

\section{SARAN}

Mengingat kacang tanah sangat bermanfaat bagi kesehatan karena kandungan protein dan lemak nabatinya, dan sulitnya mencari lahan untuk produksi kacang tanah di lahan sawah, maka disarankan untuk mengubah teknik budidaya padi dari teknik konvensional (tergenang) ke teknik budidaya sistem 
irigasi aerobik pada bedeng permanent, sehingga produksi padi dapat dilakukan secara bersamaan dengan produksi kacang tanah, baik pada musim hujan maupun pada musim kemarau, sehingga dapat mengurangi impor kacang tanah.

\section{DAFTAR PUSTAKA}

Bethlenfalvay G. J., Reyes-Solis, M. G., Camel, S. B., and Eerrera-Cerrato, R. (1991) 'Nutrient transfer between the root zones of Soybean and Maize Plants Connected by a common Mycorrhizal Mycelium'. Physiologia Plantarum, 82: 423-432.

Chu, G. X., Shen, Q. R., and Cao, J. L. (2004) 'Nitrogen Fixation and N Transfer from Peanut to Rice Cultivated in Aerobic Soil in an Intercropping System and its Effect on Soil N Fertility'. Plant and Soil, 263: 17-27.

Dulur, N.W.D., Wangiyana, W., Farida, F., and Kusnarta, I.G.M. (2019) 'Improved Growth and Yield Formation of Red Rice under Aerobic Irrigation System and Intercropping with Peanuts'. IOSR Journal of Agriculture and Veterinary Science, 12(8): 12-17. Available at : http://iosrjournals.org/iosr-javs/papers/Vol12-issue8/Series-1/C1208011217.pdf.

Hamel, C., and Smith, D. L. (1991) 'Interspecific N-transfer and Plant Development in a Mycorrhizal Field-grown Mixture'. Soil Biology and Biochemistry, 23: 661-665.

Harsono, A. (2012) 'Inovasi Teknologi Budidaya Berbasis Pengelolaan Tanaman Terpadu untuk Meningkatkan Produksi Kacang Tanah'. Orasi Pengukuhan Profesor Riset Bidang Budidaya Tanaman. Kementerian Pertanian dan Lembaga Ilmu Pengetahuan Indonesia. Bogor, 5 April 2012 .

Hutabarat, B. (2003) 'Prospect of Feed Crops to Support the Livestock Evolution in South Asia: Framework of the Study Project'. In Proc. of Workshop on the CGPRT Feed Crops Supply/Demand and Potential/Constraints for Their Expansion in South Asia held in Bogor. Indonesia. Sept 3-4. 2002. CGPRT Centre Monograph No. 42. Bogor. Indonesia.

Inal, A., Gunes, A., Zhang, F., and Cakmak, I. (2007) 'Peanut/maize Intercropping Induced Changes in Rhizosphere and Nutrient Concentrations in Shoots'. Plant Physiology and Biochemistry, 45: 350-356.

Iryani, E., Wangiyana, W., dan Dulur, N. W. D. (2019) 'Pertumbuhan dan Hasil Berbagai Varietas Kacang Tanah antara Penanaman secara Monokrop dan bersama Padi Beras Merah pada Sistem Irigasi Aerobik'. Crop Agro, 12(1): 59-68.

Kasno, A., dan Harnowo, D. (2014) 'Karakteristik Varietas Unggul Kacang Tanah dan Adopsinya oleh Petani'. Iptek Tanaman Pangan, 9(1): 13-23.

Park, S. E., Benjamin, L. R., and Watkinson, A. R. (2003) 'The Theory and Application of Plant Competition Models: an Agronomic Perspective'. Annals of Botany, 92: 741-748.

Purba, F. H. K. (2012) 'Potensi Pengembangan Kacang Tanah dalam Peluang Usaha di Berbagai Daerah Indonesia'. Available at : http://heropurba.blogspot.com/2012/11/potensipengembangan-kacang-tanah-dalam.html. Diakses 3 Juli 2020.

Riley, J. (2001) 'Presentation of Statistical Analyses'. Experimental Agriculture, 37: 115-123.

Santosa, B. A. S. (2009) 'Inovasi Teknologi Defatting: Peluang Peningkatan Diversifikasi Produk Kacang Tanah dalam Industri Pangan'. Orasi Pengukuhan Profesor Riset Bidang Pengolahan Hasil. Badan Litbang Pertanian. Bogor.

Shen, Q., and Chu, G. (2004) 'Bi-directional Nitrogen Transfer in an Intercropping System of Peanut with Rice Cultivated in Aerobic Soil’. Biol Fertil Soils, 40: 81-87.

Wangiyana, W., Aryana, I.G.P.M., and Dulur, N.W.D. (2019) 'Increasing Yield Components of Several Promising Lines of Red Rice Through Application of Mycorrhiza Bio-Fertilizer and Additive Intercropping with Soybean in Aerobic Irrigation System'. International Journal of Environment, Agriculture and Biotechnology, 4(5): 1619-1624.

Wangiyana, W., Aryana, I.G.P.M., and Dulur, N.W.D. (2021b) 'Mycorrhiza Biofertilizer and Intercropping with Soybean Increase Anthocyanin Contents and Yield of Upland Red Rice 
Under Aerobic Irrigation Systems'. IOP Conf. Ser.: Earth Environ. Sci., 637 012087. DOI: https://dx.doi.org/10.1088/1755-1315/637/1/012087.

Wangiyana, W., Aryana, I.G.P.M., Gunartha, I.G.E., and Dulur, N.W.D. (2017) 'Effects of Inoculation with Arbuscular Mycorrhizal Fungi on Growth and Yield of Promising Line of Red Rice Grown Together with Several Peanut Varieties'. IOSR Journal of Agriculture and Veterinary Science, 10(9): 18-23. Available at : http://iosrjournals.org/iosr-javs/papers/Vol10issue9/Version-2/D1009021823.pdf

Wangiyana, W., Aryana, I.G.P.M., Gunartha, I.G.E., and Dulur, N.W.D. (2018a) 'Intercropping with Soybean and Inoculation with Arbuscular Mycorrhiza to Increase Panicle Production of Various Promising Lines of Upland and Amphibious Red Rice on Aerobic System'. Pros. Sem. Nas. Lingk. Lahan Basah, 3(2): 388-393. Available at : http://snllb.ulm.ac.id/prosiding/index.php/snllb-lit/article/view/86/84.

Wangiyana, W., Aryana, I.G.P.M., Gunartha, I.G.E., and Dulur, N.W.D. (2018b) 'Pengaruh Inokulasi Mikoriza terhadap Komponen Hasil Padi Sistem Pengairan Aerobik yang Ditumpangsarikan dengan Kacang Hijau'. AgriTECH (UGM), 18(3): 234-240 DOI: https://doi.org/10.22146/agritech.29062

Wangiyana, W., Dulur, N.W.D., Farida, N., and Kusnarta, I.G.M. (2021a) 'Additive Intercropping with Peanut Relay-Planted Between Different Patterns of Rice Rows Increases Yield of Red Rice in Aerobic Irrigation System'. Emirates Journal of Food and Agriculture, 33(3): 202-210, Apr. 2021, DOI: https://doi.org/10.9755/ejfa.2021.v33.i3.2661.

Wangiyana, W., Farida, N., and Abdurrachman, A. (2020a) 'Relay-planting of Peanuts Between Double or Triple Rows at Different Dates Increases Growth, Nitrogen Content, and Yield of Red Rice Under Aerobic Irrigation Systems'. International Journal of Environment, Agriculture and Biotechnology, 5(5):1378-1382. DOI: https://dx.doi.org/10.22161/ijeab.55.26.

Wangiyana, W., Farida, N., Zubaidi, A., and Suliartini, N.W.S. (2020b) 'Improvement of Red Rice Yield by Changing from Conventional to Aerobic Irrigation Systems Intercropped with Soybean at Different Dates'. International Journal of Environment, Agriculture and Biotechnology, 5(6): 1653-1658. DOI: https://dx.doi.org/10.22161/ijeab.56.32.

Wangiyana, W., Ngawit, I.K., Farida, N., Dulur, N.W.D., and Zainab, S. (2020c) 'Organic and Biofertilizer Application to Increase Yield of Black Rice under Aerobic Irrigation System and Intercropping with Peanut'. Proc. Intl. Conf. on Science and Technology (ICST), 1: 9-15. Available at : http://procceding.unram.ac.id/index.php/icst/article/view/20.

Warsana (2013) 'Introduksi Teknologi Tumpangsari Jagung dan Kacang Tanah'. Badan Litbang Pertanian. Available at : http://www.litbang.deptan.go.id/artikel/one/234/. Diakses pada 19 Desember, 2018.

Xue, Y., Xia, H., Christies, P., Zhang, Z., Li, L., and Tang, C. (2016) 'Crop acquisition of phosphorus, iron and zinc from soil in cereal/legume intercropping systems: a critical review'. Annals of Botany, 117: 363-377. 